\title{
The Plain Mennonite Face of the World War One Conscientious Objector
}

\author{
Donald Eberle $^{\mathrm{a}}$ \\ Adjunct Instructor \\ Arts and Sciences \\ Northwest State Community College
}

\begin{abstract}
World War One was a difficult time for American Mennonites. Conscription revealed profound differences between progressive Mennonites such as those from the General Conference and plain Mennonites such as those from the Mennonite Church. The General Conference endorsed non-combatant service and advised its draftees to "accept only service designed to support and to save life." The Mennonite Church, however, categorically rejected non-combatant service and declared that "under no circumstances can they consent to service, either combatant or noncombatant, under the military arm of the government." Military officers and government officials tended to view all Mennonites in a strictly adversarial fashion and usually failed to recognize or appreciate their differences or the sincerity of their efforts to reach some sort of mutually satisfactory compromise. Conscription defined a generation of young men and produced its fair share of martyrs. One hundred and thirty-eight Mennonites, most of them plain, were courtmartialed for refusing to accept noncombatant service. But in a counterintuitive way, conscription also strengthened the Mennonite Church. The young Mennonite men realized the tension between their religious beliefs and the expectations of them as citizens of the United States. They almost invariably reported that whatever suffering they endured because of their nonresistant stand ultimately strengthened their faith.
\end{abstract}

\section{Keywords}

Conscription; Conscientious objectors; Defenselessness; First World War; Furlough Act; General Conference; Loucks, Aaron; Mennonites on Military Service; Noncombatant service; Nonresistance; (Old) Mennonite Church; Selective Service Act, 1917; Yellow Creek conference 


\section{Draft Evaders and Conscientious Objectors}

The United States declared war on Germany on April 6, 1917. Congress passed the Selective Service Act six weeks later on May $18^{\text {th }}$. For just the second time in history, and the first time since the Civil War, national conscription was once again a reality in the United States. Conscription had been extremely divisive during the Civil War, when just eight percent of the United States military was drafted. The public, as well as many politicians and military officers, questioned its effectiveness and whether it had been worth the trouble. Conscription remained controversial, and this time it impacted a far larger segment of the American public. During World War One nearly 24 million American men were registered, more than 4 million were selected, and 2.8 million men, including over 2,000 Mennonites were actually conscripted. This represented 72 percent of those who served. ${ }^{1}$

Prior to the passage of the Selective Service Act, public opinion strongly favored voluntary "patriotic" enlistments, which were considered both more masculine and democratic than conscription. Enoch Crowder, Judge Advocate General of the United States Army, argued in 1917 that a military draft was "not in harmony with the spirit of our people" and that "all of our previous experience has been that it causes trouble and that our people prefer the volunteering method."2 Once the Selective Service Act became law however, a new, more positive assessment of conscription emerged. Crowder was appointed Provost Marshall and would be responsible for drafting the Selective Service Act and implementing conscription. Like many military officers and politicians he quickly and effortlessly transitioned from being a critic of conscription to become one of conscriptions greatest advocates.

These "conscriptionists" were quick to dismiss any lingering concerns (and question the loyalty) of anyone who continued to oppose conscription. Opponents of conscription were denounced as anti-American, and accused of being pro-German. Former president Theodore Roosevelt alleged that "the bulk of the conscientious objectors were slackers, pure and simple, or else traitorous pro-Germans." 3 He denounced opponents of conscription as "professional pacifists, poltroons, and college sissies." " President Wilson did nothing to improve the perception of conscientious objectors and other pacifists when he announced "what I am opposed to is not the feeling of the pacifist, but their stupidity. My heart is with them, but my mind has a

\footnotetext{
${ }^{1}$ Robert H. Zieger, America's Great War: World War I and the American Experience (Lanham: Rowman \& Littlefield Publishers, Inc., 2000), 61.; Christopher Capozzola, Uncle Sam Wants You: World War I and the Making of the Modern American Citizen (Oxford: Oxford University Press, 2008), 18.

${ }^{2}$ Meirion Harries and Susie Harries, The Last Days of Innocence: America at War, 1917-1918 (New York: Random House, 1997), 91-92.

${ }^{3}$ H.C. Peterson and Gilbert C. Fite, Opponents of War, 1917-1918, (Madison: University of Wisconsin Press, 1957), 136.

${ }^{4}$ Theodore Roosevelt, quoted in Jack McCallum, Leonard Wood: Rough Rider, Surgeon, Architect of American Imperialsim (New York: New York University Press, 2006), 263.
} 
contempt for them. I want peace, but I know how to get it, and they do not."5

There were no large scale anti-conscription riots in the United States during World War One, as there had been in New York City in 1863, but support for conscription was far from universal. Individual acts of nonviolent draft evasion were widespread. Hundreds of thousands of men failed to register, others registered but did not report to their local boards, and still others deserted after being inducted. When the United States declared war, neither federal, state, nor local governments possessed the capabilities to identify or locate these evaders, though the Federal government quickly began to build that capability. By June 30, 1918, the Justice Department had conducted 220,747 investigations of men who had failed to register, and had initiated 10,000 prosecutions in cases where the failure to register appeared to be "clearly willful." 6 These draft resisters attempted to evade the law and posed a challenge to conscription because of their sheer numbers, but they did not directly challenge the legitimacy of the law.

Conscientious objectors, though far fewer in number, posed a greater, more existential threat. They made no effort to evade the law, instead they registered and if inducted they reported to the military authorities. They voluntarily placed themselves under the physical control of the military but then refused to recognize military authority or accept military service. They claimed the right to exemption not only for themselves, but for others like them. They directly challenged the legitimacy of the Selective Service Act and the government's right to compel their service. In the process, they challenged the prevalent understanding of the rights and duties of citizenship.

Conscientious objectors were a remarkably diverse lot, and each conscientious objector's journey was unique, but certain men were far more likely than others to become conscientious objectors. Some men based their objection upon political or humanitarian principles. The War Department estimated that about 10 percent of all objectors were "political." Most of these "political objectors" were Socialists, but the war divided the Socialist movement and many Socialists accepted military service. The vast majority of conscientious objectors based their objections upon religious beliefs. Most of the religious conscientious objectors belonged to one of the recognized historic peace churches: the Friends (Quakers), the Mennonites, and the Brethren.

Regardless of their motives, the first step for any man who claimed conscientious objector status was to appear before one of the 4,648 local exemption boards. The attitude of these exemption boards towards conscientious objectors varied, though few could truly be described as sympathetic. These local exemption boards had some discretion in granting

\footnotetext{
${ }^{5}$ Ray Stannard Baker and William E. Dodd, eds., Woodrow Wilson, “Address to the American Federation of Labor Convention at Buffalo, New York," November 12, 1917, Public Papers of Woodrow Wilson, Vol. I: War and Peace, Presidential Messages, Addresses, and Public Papers (New York: Harper \& Brothers Publishers, 1925-1927), 120.

${ }^{6}$ Robert Coakley, Paul J. Scheips and Emma J. Portuondo, Antiwar and antimilitary activities in the United States, 1846-1954 (Washington D.C.: Histories Division, Office of the Chief of Military History, Dept. of the Army, 1970), 77.
} 
exemptions, especially in the case of men who could base a claim upon several factors such as dependent children or elderly parents, but the exemption for conscientious reasons was from combatant duty only. The clear intent of the Selective Service Act was to spread the obligation for military service broadly throughout the eligible population. If a local board was convinced that a registrant qualified as a conscientious objector they would issue the man a certificate of exemption on conscience grounds, Form 1008, which he would then present to military officials when he arrived in camp, but the draftee remained liable for noncombatant duty.

Regardless of how the local board ruled, the inductee had to validate his claim again after arriving at camp and convince skeptical military authorities of his sincerity. A total of 20,873 men made conscientious objector claims to their local boards, and were subsequently inducted into the army. Just 3,989 of these men actually claimed conscientious objector status in camp. Certainly the physical and mental duress and "inhuman treatment" designed to test the "genuineness" of their convictions convinced many to drop their claim. ${ }^{7}$ Slightly more than half of the 3,989 men who claimed conscientious objector status in camp were Mennonites. ${ }^{8}$ The government did not usually distinguish between progressive, conservative, or Old Order Mennonites, but members of the conservative and Old Order groups were much more likely to press their claim in camp and they were more likely to refuse noncombatant service even if that meant a court-martial and imprisonment. Thus the public face of the religious conscientious objector in the United States was that of a plain Mennonite.

\section{The American Mennonites and Their Experience Prior To the First World War}

The Mennonites originated in Switzerland and Germany early in the sixteenth century. Named after Menno Simons (1496-1561), a former Catholic priest, they believed in the separation of the church and the state, and to some extent the separation of the church from the surrounding culture. They respected secular government but insisted that there were certain religious matters over which secular government had no authority. They rejected the authority of the state churches of Europe and were viewed as heretics and severely persecuted. Their early history, chronicled in great detail in Martyrs Mirror, is full of tales of persecution and martyrs. The Bible and Martyrs' Mirror, first published in 1660, were fixtures in almost every Mennonite home during World War One.

Persecutions in Europe, coupled with the promise of abundant land and a welcome invitation from William Penn, encouraged the first Mennonite migrations to North America. They settled in Germantown, Pennsylvania in 1683. Sizeable Mennonite communities existed in Pennsylvania, Maryland, and Virginia prior to the American Revolution. Ervin Stutzman notes

\footnotetext{
${ }^{7}$ Peterson and Fite, Opponents of War, 126.; U.S. War Dept, Statement Concerning the Treatment of Conscientious Objectors in the Army, prepared by Colonel James S. Easby-Smith, Judge Advocate (Washington: U.S. Government Printing Office, 1919), 9.

${ }^{8}$ Guy Franklin Hershberger, War, Peace, and Nonresistance, (Scottdale, Pa. Herald Press, 1981), 110.
} 
that these immigrants subscribed to a two-kingdom theology, and perceived themselves as belonging to God's kingdom first. Members of the church were strictly prohibited from participating in warfare, but that was just the beginning of their pacifism. They subscribed to the doctrine of defenselessness or nonresistance, the belief that it was wrong to use force against others even in the case of self-defense. Stutzman describes nonresistance as a "logical extension of two-kingdom theology and the doctrine of nonconformity." He notes that nonresistance was a "defining feature of Mennonite theology and practice." 9

Practicing nonresistance while also respecting civil authorities requires a delicate balance under the best of circumstances, and it becomes even more challenging during times of war. Both the French and Indian War and the Revolutionary War tested the North American Mennonite communities, but an even greater, more sustained test of their nonresistance beliefs occurred during the Civil War. The Enrollment Act, which became law on March 3, 1863, was the first national draft in United States history. All male citizens between the ages of 20 and 45 as well as all male immigrants who had taken out naturalization papers were required to register. Many Mennonites accepted noncombat work, often in hospitals, while others took advantage of a provision in the Enrollment Act which allowed them to hire a substitute or pay a commutation fee. ${ }^{10}$ The Civil War experience left a deep impression on all of the historic peace churches and resulted in a good deal of self-reflection and self-criticism. Many Mennonites felt that hiring a substitute to go to war in their place was no different than going to war themselves, but the computation fee, which was pledged for "the benefit of the sick and wounded soldiers" and more importantly was construed as a tax, was generally viewed as acceptable. ${ }^{11}$

The Spanish-American War was fought entirely by volunteers, and the Universal Military Service Act in 1903 specifically exempted members of religious organizations opposed to war so nonresistant people had plenty of time - 52 years from the end of the Civil War to the passage of the Selective Service Act - to consider their position regarding conscription.

\section{The Mennonite Church (Plain) and General Conference (Progressive)}

On the eve of the First World War there were more than a dozen Mennonite sects in the United States. The Mennonite Church (MC) - sometimes familiarly called the (Old) Mennonite Church - and the General Conference Mennonite Church (General Conference) were the two largest Mennonite bodies in the United States. Together they accounted for over half of all Mennonites living in the United States during World War I.

\footnotetext{
${ }^{9}$ Ervin R. Stutzman, From Nonresistance to Justice: The Transformation of Mennonite Church Peace Rhetoric, 1908-2008, Studies in Anabaptist and Mennonite History No. 46 (Scottdale, Pa.: Herald Press, 2011), 40-41.

${ }^{10}$ Statement Concerning the Treatment of Conscientious Objectors in the Army, 14.; and Edward Needles Wright, Conscientious Objectors in the Civil War (New York: A.S. Barnes \& Company, Inc., 1961), 219.

${ }^{11}$ John L Ruth, The Earth is the Lord's: a Narrative History of the Lancaster Mennonite Conference, Studies in Anabaptist and Mennonite History No. 39, (Scottdale, Pa.: Herald Press, 2001), 564-565.
} 
Most (Old) Mennonites were descendants from immigrants who had come some 150 years earlier from Switzerland and the Palatinate. Though they had a much longer history in the United States, most (Old) Mennonites were less assimilated and far more conservative than most General Conference churches. Members of the Mennonite Church were more likely to speak German, especially at home, though most were also fluent in English. The Mennonite Church was also stricter in regard to the doctrine of nonconformity, which was enforced when necessary by denying the offender the right to participate in communion. The (Old) Mennonite Church, with 34,965 members, was the largest Mennonite group in the United Stated during the First World War. $^{12}$

The General Conference of the Mennonites in North America (General Conference) was formed in 1860 when a group of progressive churches that had earlier broken from the Franconia conference merged with a group of Iowa churches. They sought "a more outward-looking Mennonite church" and hoped to unify all North American Mennonites, but the (Old) Mennonites had a very different view of the world and had little interest in joining them. ${ }^{13}$ The General Conference emphasized progress and rational thinking. They emphasized higher education, embraced missions and Sunday schools, and championed the church's role in improving society. At the turn of the twentieth century they were more optimistic about the prospects for world peace. ${ }^{14}$

The General Conference might have remained a relatively obscure conference were it not for a large influx of ethnic German immigrants from Russia, who migrated to the United States in the 1870's. Most of these immigrants settled in Kansas, Nebraska, and Oklahoma and affiliated with the General Conference. ${ }^{15}$ The General Conference Mennonite Church had 15,407 members in $1916 .^{16}$

The Mennonite Church was the largest of the plain Mennonites while the General Conference was the largest of the progressive Mennonites. Ervin Stutzman notes that the two groups had "little social interaction or knowledge of each other." Part of this is due to difference in ethnicity and national origins, but there was also considerable difference between them in the importance that they placed upon the practice of nonconformity with the world. The Selective Service Act revealed that there was also considerable difference in their understanding of nonresistance. Stutzman points to John Horsch and Guy Hershberger as early leaders of the Mennonite Church who "articulated the clear distinction between worldly pacifism and biblical

\footnotetext{
${ }^{12}$ United States, Bureau of the Census, Religious Bodies, 1916. Table 5. Church Members, by Principal Denominations: 1916, 1906, and 1890 (Washington: Govt. Print. Off., 1920), 30.

${ }^{13}$ Melanie Springer Mock, Writing Peace: The Unheard Voices of Great War Mennonite Objectors (Telford, Pennsylvania: Pandora Press U.S. 2003), 39.

${ }^{14}$ Stutzman, From Nonresistance to Justice, 22.

${ }^{15}$ Ibid., 41-42.

${ }^{16}$ United States, Bureau of the Census, Religious Bodies, 1916., 30.
} 
nonresistance." He argues that none of the early General Conference leaders made such a clear distinction. Stutzman also notes that Mennonite Church congregations were much more consistent in expelling men who served in the military than General Conference churches which rarely applied this form of church discipline. ${ }^{17}$ There are several reasons for this difference in their application of nonresistance to the challenge of conscription. The most significant factor, however, is the fundamentally different approach of the plain and the progressive traditions to the practice of nonconformity with the world.

The (Old) Mennonite Church organized under a central conference, the Mennonite General Conference, in 1898 and met biennially until 1971. The Mennonite General Conference was strictly an advisory body and church authority continued to reside in the independent district conferences. Despite this complicated structure and the absence of any binding authority, the pronouncements of the Mennonite General Conference on matters of faith carried great weight and had tremendous influence upon the various district conferences, which comprised the Mennonite Church. ${ }^{18}$

James C. Juhnke notes that by 1914 the (Old) Mennonite Church had achieved "more organizational solidarity and uniformity" than the General Conference had. Juhnke notes that "effective authority" in the (Old) Mennonite Church, rested with the bishops who "ran the various (and much older) district conferences, and established and enforced rules for church procedures and personal styles of life." Juhnke argues that the World War would "show how successfully the (Old) Mennonites' general conference might set standards for bishops to enforce at the district and local level." He notes, for example, that the conference adopted a strong statement against taking part in "carnal warfare" in 1915 at Archbold, Ohio. Members who "bore arms" were to be "disowned from membership." Two years later, at the Yellow Creek church in northern Indiana, the conference adopted "the most comprehensive statement on military service made by any Mennonite group during the war."19

The war which broke out in Europe in 1914 was troubling to all American Mennonites, but for nearly three years it was also distant. So long as the United States remained neutral, there was no immediate problem. Allan Teichroew argues that "Mennonites were an isolated people in World War I. The average Mennonite, General Conference, (Old) Mennonite, Amish, or other, paid scant attention to the problems created by the failure of international diplomacy." 20 However, the Declaration of War, followed closely by the Selective Service Act, was devastating.

The factious nature of the Mennonite community, divided into many competing and

\footnotetext{
${ }^{17}$ Stutzman, From Nonresistance to Justice, 25.

${ }^{18}$ Bender, Harold S. "Mennonite Church General Conference." Global Anabaptist Mennonite Encyclopedia Online. 1956. Web. 11 October 2012. http://www.gameo.org/encyclopedia/contents/M46611ME.html.

${ }^{19}$ James C. Juhnke, Vision, Doctrine, War: Mennonite Identity and Organization in America, 1890-1930 (Scottdale, Pennsylvania: Herald Press, 1989), 213.

${ }^{20}$ Allan Teichroew, "Mennonites and the Conscription Trap," Mennonite Life, September 1975, 10.
} 
jealous sects, did not serve any of them particularly well when they were confronted with conscription in 1917. It made it difficult to speak with one voice and almost impossible for them to effectively reach out to other peace churches or secular peace organizations to present a united front to the government. As a result, there was a lot of duplicated effort, as numerous Mennonite sects sent delegations to Washington, D.C., seeking information and promises that their members would be exempted from compulsory military service. This was also frustrating to government officials, as some Mennonite groups eventually relaxed their opposition to noncombatant service. The General Conference, Mennonite Brethren, and Krimmer Mennonite Brethren all indicated that they would accept "service in agricultural or the Red Cross and failing that, might even agree to do non-combatant work." Melanie Mock points out in Writing Peace: The Unheard Voices of Great War Mennonite Objectors that these offers of service "contradicted the position of other groups. (Old) Mennonites took a firmer stance in their discussions with government authorities, rejecting any form of duty under military government, combatant or noncombatant." 21

This lack of unity was especially detrimental to the Mennonite Church and other plain Mennonites. It hindered their efforts to introduce themselves and explain their beliefs to government officials and to the broader American public. This lack of unity allowed their image to be controlled by military officials who were inherently skeptical of conscientious objectors and by critics who were less than sympathetic. This is not to say that a united effort to educate the public and selective service officials would have made much of a difference. The positions of the Mennonite Church and the government relative to conscription were quite far apart. This lack of agreement and coordination, however, did not help the situation. Government officials can perhaps be forgiven for their failure to comprehend why plain Mennonites continued to refuse noncombatant service when others, in particular the General Conference, had agreed to accept it. This lack of unity was the result of significant differences in outlook and not from a lack of effort.

I. A. Sommer, editor of The Mennonite, the official English language organ of the General Conference, posed a provocative question in a 1910 editorial: "In What Fundamentals Do Mennonites Agree?" This editorial led to the first All-Mennonite Convention held at Berne, Indiana in 1910. Eight other All-Mennonite Conventions were held irregularly thereafter until 1936. None of these conventions were held while the United States was at war and only the second convention, held at Carlock, Illinois, August 30-31, 1916 occurred during World War One.

The Second All-Mennonite Convention appointed a committee to speak for Mennonites collectively, but James C. Juhnke notes that this was "an ad hoc voice." He points out that "it did not speak for the Old Order Amish and Old Order Mennonites, who had ignored the misnamed 'All Mennonite' movement." Nor did it "speak for the much larger Amish Mennonite and 'Old'

\footnotetext{
${ }^{21}$ Mock, Writing Peace, 39.
} 
Mennonite bodies, for they had specifically opposed the convention." 22 At the conclusion of the convention, the delegates sent a petition to President Woodrow Wilson expressing their conviction "that war can never serve as an effective solution to international complications" and that "arbitration and other conciliatory methods, rather than military force, should be encouraged as a far better instrument for the securing of international justice." ${ }^{23}$ Although this statement was issued by the more progressive Mennonites, the plain Mennonites certainly agreed with the sentiment. There was, however, considerable disagreement between the progressive and the plain churches over the likelihood that arbitration would work and how to respond in the event that it failed.

\section{The Selective Service Act and Mennonites on Military Service}

The Selective Service Act became effective on May 18, 1917. It provided exemptions for ... well-recognized religious sects or organizations at present organized and existing and whose existing creed or principles forbid its members to participate in war in any form and whose religious convictions are against war or participation therein in accordance with the creed or principles of said religious organizations, but no person so exempted shall be exempted from service in any capacity that the President shall declare to be noncombatant. $^{24}$

Mennonites certainly qualified as members of well-recognized religious sects. However, a period of uncertainty followed as regulations governing exemptions and defining non-combatant service were drafted.

Registration Day was held on June 5, 1917. Although the president had not yet defined what constituted non-combatant service, Allan Teichroew explains that Registration Day "brought no difficulty from any Mennonites" because "none of the Mennonite groups opposed registration on principle." He adds that the Exemption Committee of the General Conference considered "registration to be as innocuous as a census" while the official organ of the Mennonite Church, the Gospel Herald, reasoned that "to obey it was in accord with the Biblical teaching which taught that Christians should be subject to the powers that be." The Gospel Herald added that it provided "an opportunity to make an important public witness on the issue of nonresistance." 25

Having avoided the first two All-Mennonite Conventions, which were sponsored by the

\footnotetext{
${ }^{22}$ Juhnke, Vision, Doctrine, War: 222-223, 229.

${ }^{23}$ Petition from All-Mennonite Convention at Carlock, Illinois, to President Woodrow Wilson, August 30-31, 1916, Henry R. Voth files, MSS BCHL, folder 87-88. Mennonite Church USA, Archives- North Newton. North Newton, Kansas.

${ }^{24}$ An Act to authorize the President to increase temporarily the Military Establishment, approved May 18, 1917, Public Law No. 12, $65^{\text {th }}$ Congress, H.R. 3545, U.S., Statutes at Large, XL, Part 1, 78.

${ }^{25}$ Teichroew, "Mennonites and the Conscription Trap," 11.
} 
General Conference, 199 delegates representing sixteen district conferences of the (Old) Mennonite Church from the United States, Canada, and India met at the Yellow Creek Church near Goshen, Indiana, on August 29, 1917 to address war related issues. The Yellow Creek conference, which was held nearly two months after registration day, was not as timely as the first two All-Mennonite Conventions but it took two very significant actions. First, it selected Bishop Aaron Loucks, to head the Military Problems Committee. Loucks would be a vigorous and effective advocate in representing the Mennonite Church in its interactions with the government and the public. ${ }^{26}$ Equally as important, the delegates issued a statement at the conclusion of the conference which represented a clear "expression of our position on the doctrine of nonresistance as applied to present condition brought on by the world war now raging." This statement, Mennonites on Military Service-sometimes referred to as the Yellow Creek statement - was much more direct and confrontational than the Petition from the AllMennonite Convention, which had been issued the previous year. A number of factor explain the difference in tone between the two documents, not the least of which was the fact that the Mennonites on Military Service, represented the views of the plain (Old) Mennonite Church. The fact that the United States was now a belligerent, and no longer neutral, was also significant.

Mennonites on Military Service began by stating that "we hold that Christian people should have no part in carnal warfare of any kind or for any cause." The statement claimed protection offered under "Selective Draft Law enacted May 18, 1917," noting that they were one of the churches "whose existing creed or principles forbid its members to participate in war in any form and whose religious convictions are against war or participation therein." The statement expressed deep regret, however, that the exemption was "practically nullified (save in the matter of bearing arms)" by the "further provision empowering the government to impress non-resistant people into noncombatant service."27

Mennonites on Military Service then restated their Confession of Faith adopted at Dortrecht, Holland in 1632 noting that

... this position has been uniformly held by our forefathers from Reformation times and their loyalty and devotion to their faith is attested by their suffering, even to the extent of martyrdom and banishment by those governments enjoining military service upon their citizens.

It admitted an apparent tension in their doctrine that

even laws which may seem unwise and unjust should be submitted to uncomplainingly

\footnotetext{
${ }^{26}$ The Military Problems Committee would change its name to the Peace Problems Committee in 1919. Loucks continued to head the committee until 1925.

${ }^{27}$ Mennonites On Military Service, A Statement of our Position on Military Service as Adopted by the Mennonite General Conference, August 29, 1917, I-1-1 6-1 Mennonite General Conference, 1898-1971. Mennonite Church USA, Archives-Goshen. Goshen, Indiana.
} 
and no thought should be entertained of doing anything but comply with all that they ask of us - unless they prescribe conditions contrary to the Gospel; in which case we should meekly but faithfully stand true to the principles of the Gospel, even if the consequences entail suffering.

It pointed out that "this position has been exemplified by the apostles (Acts 5:29) and our early church fathers." 28

Mennonites on Military Service acknowledged "Past Favors" and rejoiced "that freedom of conscience is thus recognized by the laws of our land." It noted that "We still have among us brethren who suffered for conscience's sake" during the Civil War. These brethren "recall with much gratitude the freedom from military service which that exemption secured for them." It expressed "hope that when the powers that be fully understand our position with reference to military service" that the clause in the Selective Draft Law pertaining to noncombatant service might be "accordingly modified." They very clearly stated their difficulty with noncombatant service:

... as a Christian people we have always endeavored to support the government under which we lived in every capacity consistent with the teaching of the Gospel as we understand it, and will continue to do so; but according to this teaching we cannot participate in war in any form; that is, to aid or abet war, whether in a combatant or noncombatant capacity. ${ }^{29}$

The delegates who attached their signatures to Mennonites on Military Service were quite aware of the potential consequences of their position. The delegates addressed what would become a frequent perception, that

... no one who really understands our position will accuse us of either disloyalty or cowardice; for our record had proven our submissiveness to the powers that be, and to maintain our position under present conditions requires greater courage than to accept non-combatant service.

Mennonites on Military Service included a direct appeal to the President of the United States "and all others in authority to bear with us in this attitude and not to construe our position as a lack of appreciation for past favors or as an act of disloyalty; also to grant unto us full liberty of conscience and the free exercise of our faith." 30

Mennonites on Military Service concluded with some direct recommendations "To Our Brethren Liable for Military Service." Specifically these brethren were advised to "comply with every requirement of the government" while "availing themselves of every opportunity to

\footnotetext{
${ }^{28}$ Ibid.

${ }^{29}$ Ibid.

${ }^{30}$ Ibid.
} 
present their claims for exemption." They were instructed to exercise care not to "commit any acts that could be rightfully interpreted as desertion or treason." When summoned to enter the military service, they were instructed to

present themselves to the authority and meekly inform them that under no circumstances can they consent to service, either combatant or non-combatant, under the military arm of the government, citing them to the fact that they are members of a church whose creed and principles forbid them to have part in war in any form, and their consciences coincide with this position.

Finally, they were instructed to submit "to any penalty the government may see fit to inflict, trusting the Lord for guidance and protection." 31

James C. Juhnke notes that the (Old) Mennonite's General Conference was "only an advisory body whose counsel the district conferences, some of whom were not even members, could choose to ignore." He argues that by attaching their names to the document the Mennonite Church "committed its leaders and district conferences much more deeply than it could have done merely by declaring a conference position." 32 Given that there was some uncertainty over how the government would eventually define non-combatant service, the fact that the 199 delegates signed the statement is a remarkable testament to a unity of vision and demonstrates the consensus within the Mennonite Church on the doctrine of nonresistance. ${ }^{33}$

Mennonites on Military Service was typical, if perhaps slightly more confrontational, of the statements issued by other peace churches. It clearly articulated the long standing doctrine of the Mennonite Church while being very carefully worded to stay, as much as possible, within the spirit and letter of the law. Nevertheless, Mennonites on Military Service was not received well by certain members of the government and military.

R.H. Van Deman, chief of the military intelligence branch, wrote to A. Bruce Bielaski, chief of the bureau of investigation, Department of Justice, on April 12, 1918 to report that he had received and studied a copy of Mennonites on Military Service. He drew special attention to the recommendation that "under no circumstances can they [members of the church] consent to the military service, either combatant or non-combatant, under the military arm of the government." He also noted that

... the list of Church heads and officials appear to be largely German or of German

\footnotetext{
${ }^{31}$ Ibid.

${ }^{32}$ Juhnke, Vision, Doctrine, War, 214.

${ }^{33}$ Mennonites on Military Service was signed by 48 bishops, 103 ministers, 32 deacons and 1 lay delegate of the Mennonite General Conference. It was signed by an additional 15 bishops, ministers, and deacons of "several other branches of the Mennonite Church" who "heartily" endorsed the statement but were not "affiliated in conference relations" with the Mennonite General Conference.
} 
extraction. It would seem that this resistance to the very liberal provisions of the "Selective Draft Law" regarding conscientious objectors is a very insidious piece of proGerman propaganda.

Van Deman suggested that an "investigation of the Mennonites and their activities might bring to light interesting revelations." Military officials were often not capable, or interested, in differentiating between plain and progressive groups, and tended not to notice the considerable differences between them. In this case though, it is clear that Van Deman is referring specifically to the Mennonite Church. ${ }^{34}$

Van Deman would remain suspicion of the Mennonites and their motives throughout the war. This suspicion was widespread among military officers, government officials, and the general public. Incessant government propaganda, intended to create support for the war, conditioned the public to question the patriotism and even the loyalty of anyone who dissented in even minor ways, and opposition to conscription was no minor point of disagreement and dissent.

S.C. Yoder, of Kalona, Iowa, was one of the 199 bishops, ministers, deacons, lay delegates and representatives of the Mennonite Church that had signed Mennonites on Military Service. He wrote to Aaron Loucks on Sept. 2, 1918 after he learned that Loucks had "been in communication with the Dept. of Justice, with reference to the prospective prosecution of the Ministers and Bishops who signed [Mennonites on Military Service]." Yoder wanted to find out "what the prospects are of getting into the penitentiary on that score." He reported that "all the Iowa ministers who have signed the document were called before Special Agent Sherwood, at Washington, Iowa, Saturday and a number of questions asked and statements taken." Yoder noted that Dr. Stone "is at the head of the movement to imprison all who had signed it." Yoder described Stone as "one of the worst trouble makers that I have known. ${ }^{35}$

Yoder had good reason to be concerned. In addition to the enforcement provisions contained in the Selective Service Act of 1917, a number of other pieces of wartime legislationmost notably the Espionage Act of June 15, 1917, the Trading with the Enemy Act of October 6, 1917, the Sabotage Act of April 20, 1918, and the Sedition Act of May 16, 1918 — gave the government extraordinary powers, certainly greater than it had exercised at any time since the Civil War, to compel compliance with wartime policies. It was no secret that the Justice Department considered bringing charges, under the Espionage Act, against the Mennonite leaders who had signed Mennonites on Military Service. Indictments were prepared but ultimately none of these cases were actually prosecuted. A handful of Mennonite leaders were, however, tried for

\footnotetext{
${ }^{34}$ R.H. Van Deman, Chief of the Military Intelligence Branch to A. Bruce Bielaski, Chief of the Bureau of Investigation, Department of Justice, April 12, 1918, Military Intelligence Division Correspondence, 1917-41, Box No. 3761. National Archives, College Park, M.D.

${ }^{35}$ S.C. Yoder, Kalona Iowa to Aaron Loucks, September 2, 1918, Mennonite Church USA Archives- Goshen, Peace Problems Committee 1/11 Loucks and Hartzler, 1918-1919 Correspondence Sept 1-6, 1918.
} 
other offences closely related to their criticism of the war. The two most notable cases were that of Samuel H. Miller of Sugarcreek, Ohio, and that of Lewis J. Heatwole of Randolph County, West Virginia. Both cases resulted in convictions.

A comprehensive and impartial investigation of the Mennonites and their activities would surely have revealed some interesting revelations, but perhaps not the revelations that Van Deman expected. Because Van Deman and other military officers and government officials tended to view Mennonites in this strictly adversarial fashion, they usually failed to recognize or appreciate the sincerity of their efforts to reach some sort of mutually satisfactory compromise.

\section{Efforts to Find Alternative Forms of Service}

On September 15, 1917, Secretary of War Baker ordered camp commanders to hold conscientious objectors - then estimated to be between 1,800 to 2,000 men - segregated, pending further disposition of their cases. He explicitly forbade any "punitive hardship" be inflicted upon them. On October 10, 1917, Baker issued a second confidential order which directed that draftees who refused to participate in drills were to be segregated to keep their ideas from spreading to the rest of the camp. This order specified that efforts were to be made to convince them to accept military service, but it did not clarify what steps officers could or should use, though it did specify that the attitude of conscientious objectors be "quietly ignored" and that they be treated with "kindly consideration."36

Efforts by the War Department to keep many of the policies concerning conscientious objectors secret, so as to discourage more men from coming forward with objections, resulted in a very inefficient system for relaying orders and unintentionally contributed to an environment of uncertainty that led to abuses. Lacking specific guidelines, and with innumerable other pressing concerns, camp commanders never considered conscientious objectors a high priority. Most of them seemed content not to take an active interest in the conscientious objectors while others were willfully ignorant of the physical, mental, and psychological coercion that was inflicted upon the objectors, usually by fellow soldiers or non-commissioned officers. Often this coercion amounted to abuse. Occasionally this abuse was severe and prolonged and amounted to torture. The rapid turnover of both officers and conscientious objectors made it difficult not only to relay orders promptly but also to monitor the treatment of conscientious objectors in the various military cantonments. Oversight was poor, and the War Department often learned of abuse from representatives of the historic peace churches or civil liberties organizations.

One possible solution to this problem would have been to furlough these absolutists and allow them to fulfill their non-combatant service under civilian oversight. A proposal suggesting this approach was circulated throughout the War Department as early as 1917, but Provost

\footnotetext{
36 "Confidential memo from the Adjunct General of the Army to the Commanding Generals of all National Army and Nationals Guard division camps," October 10, 1917 cited in United States, War Dept. Statement concerning the treatment of Conscientious Objectors in the Army, (Wash: Govt. Print. Off., 1919), 37.
} 
General Crowder displayed his capacity for counterintuitive reasoning and made the highly legalistic objection that the Conscription Act had authorized the President to assign inductees to non-combatant service only in "the military establishment" and did not authorize him to conscript men for civilian service. ${ }^{37}$ Conscripting men for civilian service would have been acceptable to the vast majority of conscientious objectors, but likely would have been unpopular with the general public, which was not in favor of any compromise. Crowder's opposition to this proposal, which was never a realistic option politically, dashed any hope for a quick solution to the conscientious objector problem. The idea, however, would survive and it would form the basic approach toward conscientious objectors that the United States followed during the Second World War.

The failure to reach an accommodation regarding alternative service meant that Mennonites men, like everyone else, would have a legal obligation to report to military camps if they were called by their local exemption board. Some boards recognized that it was good policy to keep conscientious objectors, who often were highly productive farmers, on the farms where they were making valuable though indirect contributions to the war effort than to send them to military camps where at best they would be a nuisance. They used what discretionary powers were available to them to keep conscientious objectors out of the military, but most boards were insistent on sending even the most adamant objectors into the military. The fact that Mennonites were geographically concentrated into a relative small number of the 4,648 local exemption districts guaranteed that even sympathetic exemption boards would send a large number of Mennonite conscientious objectors into military service.

\section{The Experience in the Camps}

The first conscientious objectors reported to military camps in late summer of 1917 . They faced the most uncertainty. Later draftees benefited from their experience and left home with a greater familiarity with military procedures, but circumstances were slightly different at every camp and procedures changed over time, so to some extent each conscientious objector faced an unfamiliar, though generally hostile, environment. All objectors, but especially the earlier objectors, were "placed in an unenviable position, uncertain of what the government would ask of them and uncertain too what the church expected of them." 38 Their diaries reveal their "profound sense of isolation and alienation, from their ethnic communities and from the communities in which they were forced to live, communities that reviled them for not wholeheartedly embracing the country's militaristic fervor." 39 Their decisions in camp revealed profound differences between progressive Mennonites such as those from the General Conference and plain Mennonites such as those from the Mennonite Church. This was particularly evident when it came to their attitudes toward non-combatant service.

\footnotetext{
${ }^{37}$ Arlyn John Parish, Kansas Mennonites During World War I, (Hays, Kansas: Fort Hays Kansas, 1968), 30.

${ }^{38}$ Mock, Writing Peace, 40.

${ }^{39}$ Ibid., 20.
} 
Gerlof Homan writes in American Mennonites in the Great War that one of the first "supposedly definitive statements of action" made by a Mennonite group was that of the General Conference, whose Exemption Committee advised its draftees in September 1917 to "accept only service designed to support and to save life. They were not to participate in any work that would result in personal injury." 40 This statement was far from definitive, and not very specific, but it clearly endorsed, at least in principle, accepting non-combatant service. The contrast with the Mennonite Church's position, as articulated in Mennonites on Military Service, that "under no circumstances can they consent to service, either combatant or non-combatant, under the military arm of the government" could not have been clearer. ${ }^{41}$ The plain Mennonite Church's position represented a categorical rejection of non-combatant service.

When a conscientious objector arrived in camp, he faced a dizzying number of decisions. Even if he was determined to refuse non-combatant service, it was not always obvious exactly where to draw the line. The consequences of every decision were enormous. This was true for all conscientious objectors regardless of the reason for their objections.

Aaron Loucks and the Military Problems Committee performed an important, though controversial, role as an intermediary between the government and the individual draft eligible Mennonites. They offered conscientious objectors, as well as potential conscientious objectors, advice on a number of topics from migrating to Canada to accepting or declining noncombat service. Any one of these topics put them at risk for legal prosecution. Loucks, because of his prominent role on the Military Problems Committee and the massive volume of inquiries he received from conscripted young men and their families, was perhaps uniquely vulnerable. He was clearly cognizant of the fact that his letters were being monitored and his every word was being closely scrutinized; however, he continued to offer advice which, at least on occasion, could have resulted in his prosecution and conviction.

One of the most common questions regarded the issue of wearing military uniforms. Most resisted the uniform, though nearly all report intense pressure to wear it. Many report that their civilian clothes were taken away, either through physical force or by subterfuge, and others report groups of soldiers physically forcing the military uniform upon them. Wilfred Gingerich Co. C. 156 Inf. Camp Beauregard, Alexandria Louisiana wrote to Aaron Loucks on June 10, 1918. Gingerich reported that he had been "compelled to put on a uniform and to drill." He added that, so far as he could tell, he was the only Mennonite in camp. He admitted that "they have me here in such a way that I don't know what to do." He wrote that he would "go to headquarters here at Camp and see what they would say" but that he could not "leave this street without the permission of the Lieut., who is doing all he can to make me drill and to keep me in

\footnotetext{
${ }^{40}$ Gerlof D. Homan, American Mennonites and the Great War, 1914-1918 (Scottdale, Pennsylvania, Herald Press, 1994), 123, 131-132.

${ }^{41}$ Mennonites on Military Service.
} 
the drilling." 42

Interestingly, Gingerich wrote a second letter to Loucks that same day. He began this second letter by admitting that "I know I am a long way from Iowa, but am in great need of some advice." He wrote that he has been in camp "three weeks next Saturday" and he is "in a uniform and drilling every day." He noted that he wrote to "several ministers two weeks ago for advise but haven't heard from them yet." Later he wrote that "they forced me into the uniform here, but haven't given us guns yet." He claimed that he "was thinking of refusing to carry one but wanted to hear from some ministers first as I haven't received any advice at all."43

Another area of concern was the matter of military pay. Like the uniform, this was not as simple a decision as it might at first seem. Ironically, had President Wilson's initial intentions been implemented, this would not have been an issue for conscientious objectors. Originally, the Wilson administration, "influenced by conscriptionists organizations and the General Staff," had proposed that "wartime citizen soldiers should serve out of patriotic duty, and therefore, need not be compensated with wages in addition to their sustenance." Congress quickly rejected this proposal and instead doubled the current pay for soldiers. Privates in the United States army received \$30 a month, along with allotments for dependents and War Risk Insurance. ${ }^{44}$

J.S. Shoemaker, of Dakota, Illinois, Secretary of the Mennonite Board of Missions and Charities (Mennonite Church), wrote to Loucks on August 5, 1918 seeking Loucks' "opinion as to what our Boys should do relative to accepting pay from the Government while in Camp." Shoemaker pointed out that presently there were "13 boys in Camp Grant." These boys were segregated in tents and "none of them have accepted service of any kind" but Shoemaker notes that they were "offered the regular monthly pay." None of the boys had accepted this offer, but "the officers are becoming insistent that they either accept the pay, or tell them what they shall do with it." Shoemaker reported that the officers told the boys that "they have no right to use it for any purpose, unless the boys say what shall be done with the money." He reported that "the boys are anxious to know what they shall do about the matter, whether they shall accept the pay, or direct that the same be turned to some other purpose." Shoemaker readily conceded that he was "at a loss to know what instruction to give them." He added that the problem was especially puzzling as the boys "not having accepted any service, either combatant or non-combatant" were

${ }^{42}$ Gingerich's letter, like many from the conscientious objectors, was written on YMCA stationary which was widely distributed to the soldiers in the camps. The stationary featured an image of the American Flag in the upper left corner and the symbol of the YMCA in the upper right. "With The Colors" was printed between these two symbols. Gingerich had carefully crossed out the slogan, "With The Colors" while leaving the Flag and the YMCA triangle untouched. Wilfred Gingerich, Camp Beauregard, Louisiana to Aaron Loucks, June 10, 1918, Peace Problems Committee 1/2 Loucks and Hartzler, 1918-1919 Correspondence June 1-30, 1918. Mennonite Church USA Archives- Goshen. Goshen, Indiana.

${ }^{43}$ Peace Problems Committee 1/2 Loucks and Hartzler, 1918-1919 Correspondence June 1-30, 1918. Mennonite Church USA Archives- Goshen. Goshen, Indiana.

${ }^{44}$ John Whiteclay Chambers, To Raise an Army: The Draft Comes to Modern America (New York: The Free Press, 1987), 167. 
"not serving the Government." Hence, in his opinion they were "not entitled to any pay, but on the other hand they are kept in Camp, and not permitted to get out on farms and earn something, and their time is worth more than the regular army salary, hence looking at it in that light they would be entitled to receiving pay." Shoemaker concluded by noting that "a few of our boys are poor and would need the pay very much." 45

J.S. Hartzler, who frequently answered Loucks correspondences, replied to Shoemaker two days later, on August 7, 1918. He advised that "the boys will be the clearest in the end if they do not accept any pay." Hartzler suggested that

The officer's suggestion is but a trap. They cannot get the money from Washington if the boys do not sign up for it. That has been tested out at Taylor. It looks in this case as if the officers wanted something to laugh up their sleeves about, or had gotten the money in some roundabout way and must produce receipts for it, and if the boys do not accept, they cannot do it.

Hartzler added another reason to refuse the pay, namely that "the War Department would not allow it to be given to anything except the Red Cross, Y.M.C.A. work, W.S.S., or something of that kind, and we are falling over each other trying to escape all these war measures." Hartzler repeated "for me, absolutely I cannot advice the boys to accept, and much less could I advise them to order it given to some of these war measures." He did concede, however, that "this may seem needlessly stiff. I will not send it without Bro. Loucks' 'Jack Robinson.' He may have something better to offer." Hartzler concludes with the somber warning that "cords are being drawn a little closer all the time, and it looks as if more suffering on the part of the Church was near at hand." As an illustration he noted that "I was chased out of Camp Gordon, very gently, but several others were handled a good deal rougher than I, and were threatened with imprisonment if they ever came back, and they were there to see their own sons." 46

Collectively, the bishops and other leaders of the Mennonite Church gave great encouragement to their young men, many of whom had never been away from home before, who were facing severe challenges. They exerted tremendous influence upon those young men who might be wavering. Try as they might, however, Mennonite ministers could not be at every camp as often as they would have liked. When Mennonite ministers were not available, military officers arranged for YMCA ministers to speak. From all indications, the plain Mennonite conscientious objectors resented this rather transparent attempt at propagandizing. The YMCA ministers routinely "voiced the country's then-predominating theology of trench salvation and holy war." One plain Mennonite conscientious objector, Ura Hostetler, recorded in his diary that

\footnotetext{
${ }^{45}$ J.S. Shoemaker, Secretary of the Mennonite Board of Missions and Charities to Aaron Loucks, August 5, 1918, Peace Problems Committee 1/11 Loucks and Hartzler, 1918-1919 Correspondence Aug 5-9 1918. Mennonite Church USA Archives- Goshen. Goshen, Indiana.

${ }^{46}$ J.S. Hartzler to J.S. Shoemaker, August 7, 1918, Peace Problems Committee 1/11 Loucks and Hartzler, 19181919 Correspondence Aug 5-9 1918. Mennonite Church USA Archives- Goshen. Goshen, Indiana.
} 
"some civilian Anti Christ was here and talked to us something awful. May God show him the light before it is to late..... Claimed to be a minister of the gospel."

\section{The Furlough Act and Non-Combatant Service Defined}

Immediately after the United States declared war, the Department of Agriculture, joined later by the Food Administration, began to mobilize America farmers. They stressed the importance of the American farmer and their "big war job." The rhetorical connection between the "patriots on the farms" and the soldier became increasingly overt as the war continued. A series of food production campaigns urged farmers to "go over the top" for great harvests. This created a natural tension between maximizing agricultural production and filling the ranks of the military.

Congress responded to this tension and passed the Furlough Act on March 16, 1918, which authorized the Secretary of War to grant furloughs to enlisted men to "engage in civil occupations and pursuits." The intent of Congress was to alleviate the shortage of agricultural labor that threatened the harvest, not to solve the problem of conscientious objectors. However, advocates for conscientious objectors quickly pointed out the absurdity of keeping conscientious objectors, who refused to accept any work in the military, from productive work in the civilian economy. The Farm Furlough Bill opened the door for alternative service and hundreds of conscientious objectors were eventually furloughed to work on farms, but the military only began to accept requests from conscientious objectors on May 31, 1918 after Crowder had advised the Secretary of War that the law also "allowed" conscientious objectors to be furloughed. $^{48}$

The Furlough Act eventually solved many of the government's conscientious objector problems, and it provided an important precedent that was later applied during World War II with even greater success. A committee of nine, composed of three representatives from each of the historic peace churches, was created to assist the government in placing conscientious objectors in civilian jobs. Although Aaron Loucks would have been a logical choice to serve on this committee, he was deliberately left off. This was mostly, perhaps entirely, because Third Assistant Secretary of War Frederick P. Keppel viewed Loucks not as a partner but as an adversary. $^{49}$

Four days after Congress passed the Furlough Act, President Wilson finally defined noncombatant service on March 20, 1918. Service with the medical corps, the quartermaster corps, and the army engineers were all designated "non-combatant." This long-anticipated announcement paved the way for the military to institute court-martial proceedings against those

\footnotetext{
${ }^{47}$ Mock, Writing Peace, 62.

${ }^{48}$ Major Walter Guest Kellogg, The Conscientious Objector (New York: Boni and Liverright, 1919), 25.

49 The Committee included three Brethren, three Friends, and three Mennonites, two of which were Old Mennonites and the third belonged to the General Conference.; Parish, Kansas Mennonites during World War One, 32.
} 
conscientious objectors who continued to refuse to accept non-combatant service. It also touched on a debate within the Mennonite Church over how to instruct their men in the army.

Surprisingly, the Mennonite Church altered its stance, however slightly, and now "encouraged men to accept some chores within the camps." While not abandoning its official position, it recognized the reality that harsher trials likely awaited those men who continued to refuse, and, as Gerlof Homan notes, "committee members also were proceeding with more caution because of concern that their recommendations to objectors might violate the Espionage and Sedition Acts." Homan specifically cites Loucks and Hartzler who not only "told Mennonite men they should not openly refuse officers' demands" but that they need also "explain 'mildly' why they found an order unacceptable." Loucks and Hartzler decided that conscientious objectors could "clean up around the barracks and cook, for in rejecting even these jobs men were bringing trials upon themselves." They could even choose to wear a uniform if they wished. They still believed that Mennonites might have to endure suffering for their beliefs, but they were confident that "suffering for Christ would be an opportunity to glorify God more than they could possibly do at home or anywhere else." Homan notes that with this evolution in recommendations, the (Old) Mennonites "came more into line with General Conference Mennonites who, even after Wilson's edict, predominately believed their men could render some service and even wear the uniform, if their conscience allowed it." ${ }^{, 50}$ Over half of the conscientious objectors who had previously refused regular service found the President's definition of non-combatant service acceptable. Most of them went to work in the medical or quartermasters corps.

Just as Loucks and Hartzler had predicted, on April 27, 1918, one month after defining non-combatant service, Secretary Baker reversed his earlier orders that the attitude of conscientious objectors be "quietly ignored" and declared that "sullen or defiant" objectors as well as those whose sincerity was questionable or that engaged in "nonresistant propaganda" would now be subject to penalties under the Articles of War and could be tried by courtmartial. ${ }^{51}$ Many within the military felt that this option was long overdue. The General Staff noted:

Efforts have been made to extend tolerance to those who have genuine religious convictions against war, by offering them non combatant service, such as the Quakers have been usually willing to perform. But there have been numbers of drafted men who have refused to wear the uniform at all or to obey any commands. If they were not dealt with rigorously the whole principle of universal service would fall to the ground. It has gone hard with those who have been led to reject the Government's tender of peaceful

\footnotetext{
${ }^{50}$ Mock, Writing Peace, 59.

51 "Orders from Adjutant General of Army to Commander of all camps," April 27, 1918, in Statement Concerning the Treatment of Conscientious Objectors in the Army, 40.
} 
tasks. $^{52}$

With the Furlough Act passed, non-combatant service finally defined, and the War Department's decision to proceed with court-martials against some conscientious objectors, the situation for conscientious objectors in the military camps began to change rapidly.

\section{The Board of Inquiry}

The War Department created a Special Board of Inquiry to interview the objectors to determine their sincerity and then make a decision regarding their eligibility for a furlough. This Special Board of Inquiry was chaired by Major Richard C. Stoddard of the Judge Advocate General's Department until he was called to duty overseas in August, after which it was chaired by Major Walter Kellogg. ${ }^{53}$ This procedure was generally acceptable to most conscientious objectors, and by nearly all religious conscientious objectors, though there were a few political conscientious objectors who strenuously objected.

Kellogg readily admitted that prior to serving on the Board he had "never set eyes on a conscientious objector," but "firmly believed that they were, as a class, shirkers and cowards." Kellogg's opinion gradually changed as he examined over eight hundred objector in twenty different military camps. He eventually came to believe that as a rule they were "sincere" and neither cowards nor shirkers, at least not "in the commonly accepted sense." He explained, however, that their sincerity "makes them no less a national problem.",54

While Kellogg generally judged Mennonites to be sincere and thus eligible for furlough, he was not impressed by them. Kellogg describes a "typical" Mennonite: "He shuffles awkwardly into the room - he seems only half awake. His features are heavy, dull, and almost bovine." ${ }^{55}$ He does not specify which group of Mennonites he is referring to as "typical" but most of the Mennonites who would have refused to accept non-combatant service - and thus appeared before the Board of Inquiry — would have been plain Mennonites.

Kellogg concluded that Mennonites were not only "ignorant" but also so "intellectually inferior" that they were "unworthy" of being American citizens. He wrote:

I doubt extremely if fifty per cent of the Mennonites examined, because of their ignorance and stupidity, ever should have been admitted into the Army at all; I am certain that ninety per cent of them need a far better preparation for citizenship than they have ever received.... They are, doubtless, according to their lights, good Christians, but they

\footnotetext{
${ }^{52}$ United States, War Department, General Staff, Propaganda In Its Military And Legal Aspects (Washington: Military Intelligence Branch, Executive Division, General Staff, 1918), 108-9.

${ }^{53}$ The remaining seats on the board were held by the Hon. Julian W. Mack of the United States Court of Appeals and Harlan Stone, Dean of the Columbia University Law School.

${ }^{54}$ Kellogg, The Conscientious Objector, v.

${ }^{55}$ Ibid., 38.
} 
are essentially a type of American of which America cannot be proud."56

The Special Board of Inquiry ultimately used a straight forward, if somewhat simple, criterion to determine a conscientious objectors' sincerity. Membership in a recognized church prior to April 6, 1917 was considered a sure indication of sincerity. Those who joined after that date were determined to be insincere. Men who were judged to be sincere were offered furloughs for civilian work, and they and the country were spared the unnecessary burden of court-martial. Most of these conscientious objectors were furloughed to work on farms. Many were sent to Iowa, South Dakota, or Kansas, where there was a particularly acute labor shortage during harvest season. In exceptional cases, the Board of Inquiry furloughed conscientious objectors, 99 in all, for service in France with the Friends Reconstruction Unit. ${ }^{57}$

Though the Special Board of Inquiry was far from perfect, and had its critics both within the military establishment and among the conscientious objectors, it was a significant step toward a better policy that served the needs of both the conscientious objectors and the nation. Harlan Stone, a member of the Special Board of Inquiry who would later became the Chief Justice of the United States Supreme Court, reflected in 1919 on the evolving treatment of conscientious objectors. Stone wrote that

... if unhappily we should again find ourselves in an armed conflict, the record of our experience with the conscientious objector, and especially the common-sense interpretation of it, will be found to be of value not only to the military authorities but to the public at large. ${ }^{58}$

Regardless of the generally skeptical attitude of many in the military, the Farm Furlough program went forward and, as the only real alternative to court-martials, it did a great deal of good in reducing "the problem" of the conscientious objector. Although there were some aspects of the program that raised concerns, most Mennonites, including the Mennonite Church, generally had a very favorable view of the Farm Furlough Program. Although Aaron Loucks was not a member of the Committee created to advise the War Department on the Farm Furlough program, his efforts in matching conscientious objectors with eligible farmers for furloughs were perhaps his most beneficial service to the government.

Loucks explained the church's eagerness to cooperate with the government in arranging furloughs in a letter to A.H. Rhodes of Columbiana, Ohio. "Our purpose" Loucks wrote, "is to help the Government find places which will be congenial to Government, to the employers, and

\footnotetext{
${ }^{56}$ Ibid., 41.

${ }^{57}$ Ibid., 29.

${ }^{58}$ Heather T. Frazer and John O' Sullivan, “We Have Just Begun To Not Fight”: An Oral History of Conscientious Objectors in Civilian Public Service during World War II (New York: Twayne Publishers, 1996), xv.
} 
to the boys." ${ }^{, 59}$ This effort was one of the rare instances in which the interests of the government and the church coincided nearly perfectly. Furloughed conscientious objectors technically remained in the military but they were now under civilian oversight. The military was relieved of uncooperative conscripts who were more a determent than an asset, and the conscientious objectors returned to productive agricultural work.

Most of the plain Mennonite conscientious objectors had been employed in agriculture before the war, many worked their own farms or on their parent's farms. Most desired to be furloughed to their homes, but government policy called for furloughing the men at least 50 miles from their local draft boards. While many Mennonites viewed this 50 mile restriction as a final, and petty, form of punishment, Loucks and other church leaders recognized it as a prudent precaution given public opinion, and firmly supported this requirement. In a letter to Joseph A. Yoder of Topeka, Indiana dated June 27, 1918, Loucks describe the requirement that men not be furloughed within 50 miles of their home as "wise" noting that "some who have been sent home are in danger of losing their lives because of the ill feeling in the community, caused by their return." 60

Numerous factors had to be considered before approving a furlough, and the church and the government had slightly different priorities, but essentially their goals were compatible. The government raised no objection to the men being furloughed to the custody of other Mennonite farmers and although it was not expressly forbidden, Loucks felt that "It is best to avoid going to relatives." ${ }^{\prime 61}$ Loucks' most important concern was that the men be sent to work for farmers that "are of the same church, or at least are sympathetic" otherwise he worried there was "likely to be trouble for all concerned." 62 The furlough application process demonstrated that the differences between the plain Mennonites and the government could be reconciled, and a solution that was satisfactory to both parties was possible.

The U.S. was involved in the First World War for just nineteen months, during which time 503 conscientious objectors were court-martialed for refusing to accept even noncombatant service. These 503 conscientious objectors represented a wide variety of religious groups as well as political and secular objectors, however, the largest single group, 138 in all, were Mennonites. Although the government did not differentiate between progressive and plain groups, it is clear

\footnotetext{
${ }^{59}$ Aaron Loucks to A.H. Rhodes, Columbiana, Ohio, I-3-5.1, Mennonite Church USA Archives- Goshen, Peace Problems Committee, 2/3 Loucks and Hartzler, 1918-1919 Correspondence August 21-26, 1918.

${ }^{60}$ Aaron Loucks to Joseph A. Yoder, Topeka, Indiana June 27, 1918, I-3-5.1, Mennonite Church USA ArchivesGoshen, Peace Problems Committee, 1/2 Loucks and Hartzler, 1918-1919 Correspondence June 1-30, 1918.

${ }^{61}$ Ibid.

${ }^{62}$ Aaron Loucks to A.H. Rhodes, Columbiana, Ohio, Mennonite Church USA Archives- Goshen, I-3-5.1, Peace Problems Committee 2/3 Loucks and Hartzler, 1918-1919 Correspondence August 21-26, 1918.
} 
that the vast majority of these were plain Mennonites. ${ }^{63}$

Despite the fact that 138 Mennonites were convicted and sentenced to Leavenworth Prison for an average of nearly twenty-years, Loucks and the Mennonite Church remained surprisingly reluctant to criticize the government. A June 27, 1918 letter to J.H. and Ira Eigsti predicted that "testing times are ahead, both for the boys and for those at home." It noted that "experience has shown that those who stand true to their convictions get thru the best." The letter argued that the "government wants to know who is true and who is trying to slip thru unjustly, and it has a right to know." It suggested that "it is advisable to take a stand but not to be obstinate." It agreed that those "whose attitude in camp is defiant" give good reason for courtmartial. It pointed out that even a court-martial "will be reviewed by officers 'higher up' before they can be carried out." The letter concluded by nothing that "there is very little danger for those who are true." ${ }^{64}$ This attitude might at first appear naïve. However, Loucks was not suggesting that the conscientious objector would avoid court marital or a conviction - these they accepted as the likely consequence of their stand, but instead he reminded them to put their faith in God and trust that their faith would ultimately see them through.

Public opinion became somewhat more sympathetic to the imprisoned conscientious objectors after the war, and the War Department was criticized for the harsh treatment that the conscientious objectors were subjected to, though much of the criticism came from the secular press and the non-religious civil liberty organizations. The Secretary of War reviewed the courtmartial cases after the war and reduced or commuted most of the sentences. In January 1919, he ordered the remaining religious objectors released and discharged from the army. A special discharge was created, neither honorable nor dishonorable, for those imprisoned as well as those who had accepted farm furloughs. This special discharge was printed on a distinctive blue paper and stated that the discharged had done no work while in the army. ${ }^{65}$

Public opinion toward conscientious objectors may have softened after the war, but the attitude of most military officers toward the Mennonites remained largely unchanged. A report on Mennonites prepared by Military Intelligence during the war noted that "the spirit of loyalty and patriotism is entirely lacking in these people, killed by the narrow prejudices and environments in which they have been brought up since their first settlement in this country."66

A second report on Mennonites, also prepared by Military Intelligence acknowledged that

\footnotetext{
${ }^{63}$ J. D. Mininger, Religious C. O. 's Imprisoned at the U.S. Disciplinary Barracks Ft. Leavenworth, Kansas (Kansas City, Kansas.; published by the author, 1919); "Statistics of Court -Martial Cases of Conscientious Objectors," in Statement Concerning the Treatment of Conscientious Objectors in the Army, 51.

${ }^{64}$ Hartzler to J.H. and Ira Eigsti, June 27, 1918, Mennonite Church USA Archives- Goshen, Peace Problems Committee 1/2 Loucks and Hartzler, 1918-1919 Correspondence June 1-30, 1918.

65 "Memorandum from the Adjutant General," Jan 17, 1919 in Statement Concerning the Treatment of Conscientious Objectors in the Army, 31.

66 “Mennonites” RG 165, (Records of the RFSG) Military Intelligence Division Correspondence, 1917-41, 10900-25 to 10902-12 Box No. 3761. National Archives, College Park, M.D.
} 
ordinarily the Mennonite "is an unobtrusive, bewiskered person, who yields obedience to the laws, so long as the laws do not conflict with his religious belief." This assessment was widely shared by most observers who were familiar with the Mennonites, and were inclined to be somewhat sympathetic to them and their religious objections. The report noted a somewhat nuanced difference in attitudes based upon generations with the older members and elders being "rock ribbed in their obstinacy" whereas the younger ones were more "disposed to cut loose from the narrow prejudices that circumscribe them," even going so far as being willing to "buy bonds and aid in many war activities." There certainly were differences in the attitudes of various Mennonite groups on issues such as nonresistance, noncombatant military service, and the willingness to subscribe to war bonds, but it is likely that the officer who compiled this report inaccurately attributed these differences to generational differences when in reality they were due to the different attitudes of the progressive and plain groups. The report included a concise but accurate statement that "as farmers, the Mennonites are 100\% efficient- as militants, $100 \%$ deficient." ${ }^{, 67}$

In a somewhat counterintuitive way, conscription during the First World War seems to have strengthened the Mennonite Church. Many draft age men seriously contemplated, often for the first time in their lives, the reality that their religious beliefs and the expectations of them as citizens of the United States might not always be in perfect harmony. The looming possibility of conscription encouraged many, who during times of peace might have postponed baptism and full membership in the church, to seek that membership as soon as they were eligible.

Conscription defined a generation of young men and produced its fair share of martyrs, but they found strength in the company of other conscientious objectors. Many formed enduring friendships with others who endured similar trials. The young Mennonite men who kept diaries, or later recorded their experience in memoirs, almost invariably reported that whatever suffering they endured because of their nonresistant stand ultimately strengthened their faith.

\section{Endnote}

${ }^{\text {a }}$ Contact information: Donald Eberle, Northwest State Community College, 22600 State Route 34, Archbold, Oh 43502; deberle@northweststate.edu

\section{Bibliography}

\section{Government Documents}

Coakley, Robert, Paul J. Scheips, and Emma J. Portuondo. 1970. Antiwar and Antimilitary Activities in the United States, 1846-1954. Washington, D.C.: Histories Division, Office of the Chief of Military History, Dept. of the Army.

\footnotetext{
67 "Mennonites"; Box 3761; Military Intelligence Division Correspondence, 1917-41; Records of the RFSG, RG 165 ; NACP.
} 
Public Papers of Woodrow Wilson, Vol. I: War and Peace, Presidential Messages, Addresses, and Public Papers, edited by Ray Stannard Baker and William E. Dodd. 1925-1927 New York: Harper \& Brothers Publishers.

United States, Bureau of the Census. 1920. Religious Bodies, 1916. Washington: Government. Printing Office.

United States, $65^{\text {th }}$ Congress, "An Act to Authorize the President to Increase Temporarily the Military Establishment, Approved May 18, 1917, Public Law No. 12, $65^{\text {th }}$ Congress, H.R. 3545," in United States, Statutes at Large, XL, Part 1, 78.

United States, War Department, General Staff. 1918. Propaganda in Its Military and Legal Aspects. Washington, D.C.: Military Intelligence Branch, Executive Division, General Staff.

United States, War Department. 1919. Statement Concerning the Treatment of Conscientious Objectors in the Army, prepared by Colonel James S. Easby-Smith, Judge Advocate. Washington, D.C.: Government Printing Office.

\section{Church Publications}

Hershberger, Guy F. 1969. War, Peace, and Non-resistance. Scottdale, PA: Herald Press.

Homan, Gerlof D. 1994. American Mennonites and the Great War, 1914-1918. Scottdale, PA: Herald Press.

Juhnke, James C. 1989. Vision, Doctrine, War: Mennonite Identity and Organization in America, 1890-1930. Scottdale, PA: Herald Press.

Mennonites on Military Service, A Statement of Our Position on Military Service as Adopted by the Mennonite General Conference, August 29, 1917, I-1-1 6-1 Mennonite General Conference, 1898-1971. Goshen, IN: Mennonite Church USA, Archives-Goshen.

Petition from All-Mennonite Convention at Carlock, Illinois, to President Woodrow Wilson, August 30-31, 1916, Henry R. Voth files, MSS BCHL, folder 87-88. North Newton, KS: Mennonite Church USA, Archives- North Newton.

Ruth, John L. 2001. The Earth is the Lord's: A Narrative History of the Lancaster Mennonite Conference, Scottdale, PA.: Herald Press.

Stutzman, Ervin R. 2011. From Nonresistance to Justice: The Transformation of Mennonite Church Peace Rhetoric, 1908-2008. Scottdale, PA: Herald Press. 


\section{Secondary Sources}

Capozzola, Christopher. 2008. Uncle Sam Wants You: World War I and the Making of the Modern American Citizen. Oxford: Oxford University Press.

Chambers, John Whiteclay. 1987. To Raise an Army: The Draft Comes to Modern America. New York: The Free Press.

Frazer, Heather T., and John O' Sullivan. 1996. “We Have Just Begun to Not Fight”: An Oral History of Conscientious Objectors in Civilian Public Service during World War II. New York: Twayne Publishers.

Harries, Meirion, and Susie Harries. 1997. The Last Days of Innocence: American at War, 1917-1918. New York: Random House.

Kellogg, Walter Guest. 1919. The Conscientious Objector. New York: Boni and Liverright.

McCallum, Jack. 2006. Leonard Wood: Rough Rider, Surgeon, Architect of American Imperialism. New York: New York University Press.

Mininger, J. D. 1919. Religious C. O.'s Imprisoned at the U.S. Disciplinary Barracks Ft. Leavenworth, Kansas. Kansas City, MO: J.D. Mininger.

Mock, Melanie Springer. 2003. Writing Peace: The Unheard Voices of Great War Mennonite Objectors. Telford, PA: Pandora Press.

Parish, Arlyn John. 1968. Kansas Mennonites during World War I. Hays, KS: Fort Hays Kansas State College.

Peterson, H.C., and Gilbert C. Fite. 1957. Opponents of War, 1917-1918. Madison, WI: University of Wisconsin Press.

Teichroew, Allan. 1975. "Mennonites and the Conscription Trap." Mennonite Life. September.

Wright, Edward Needles. 1961. Conscientious Objectors in the Civil War. New York: A.S. Barnes \& Company.

Zieger, Robert H. 2000. America's Great War: World War I and the American Experience. Lanham: Rowman \& Littlefield Publishers.

\section{Archives}

Mennonite Church USA, Archives- Goshen. Goshen, Indiana.

Mennonite Church USA, Archives- North Newton. North Newton, Kansas.

National Archives of the United States, College Park, Maryland. 